\title{
PASSIVE ACOUSTIC MONITORING OF ROARING ACTIVITY IN MALE WAPITI CERVUS ELAPHUS XANTHOPYGUS IN FAR EAST OF RUSSIA: EFFECTS OF RECORDING SITE, TEMPERATURE AND TIME OF DAY
}

\author{
Ivan Yu. Rusin ${ }^{1}$, Ilya A. Volodin ${ }^{1,2, *}$, Rimma S. Andronova ${ }^{3}$, Elena V. Volodina ${ }^{2}$ \\ ${ }^{1}$ Lomonosov Moscow State University, Russia \\ ${ }^{2}$ Moscow Zoo, Russia \\ ${ }^{3}$ Zapovednoe Priamurie, Russia \\ *e-mail:volodinsvoc@gmail.com
}

Received: 16.01.2019. Revised: 21.03.2019. Accepted: 05.05.2019.

\begin{abstract}
Passive acoustic monitoring is an actual tool for population monitoring at conservation and tourist areas. This study provides detailed knowledge of roaring activity of male Far-East wapiti (Cervus elaphus xanthopygus) in the rut period of 2017 at three sites of most active rut at the $453.4 \mathrm{~km}^{2}$ territory of the State Nature Reserve «Bolshekhekhtsirsky» (Far East of Russia). Rutting calls were recorded for $5 \mathrm{~min} / \mathrm{h}$ throughout the 58 -day rut period by using three automated recording devices, one in each site, with simultaneous registration of temperature, once per hour. In total, we recorded 3474 rutting calls $(1538,1159$ and 777 calls in the three sites respectively). In each site, the roaring activity (calculated as the mean daily number of calls/h) demonstrated a similar dynamic of three rut phases: start phase, active phase and fading phase. Although the roaring activity displayed a positive correlation between sites, the actual values of the mean number of calls/h differed between sites. This finding indicates the different use of the three sites by males during the rut. At any site, the roaring activity was related to time of day (hourly); it was the highest between 03:00 a.m. and 06:00 a.m. and nearly lacked between 10:00 a.m. and 6:00 p.m. At any site, the number of calls/h increased steadily from 8:00 p.m. to 03:00 a.m. to a maximum value and then rapidly decreased from 06:00 to 09:00 a.m. to a minimum value. The effect of temperature on the daily and hourly roaring activity was weaker than the effect of time of day. We discuss the results with similar data of another protected Russian population of Far-East wapiti inhabiting the State Nature Reserve «Ussuriysky».
\end{abstract}

Key words: diurnal and seasonal dynamic, non-invasive management, Protected Area, red deer, rutting calls, ungulate

\section{Introduction}

Acoustic monitoring is an effective tool for managing populations and estimating site use and movement patterns of different animal taxa and the state of ecosystems (Obrist et al., 2010; Sugai et al., 2018). This approach has proved to be useful for insects (Jeliazkov et al., 2016; Desjonquères et al., 2018), fishes (Setyawan et al., 2018), amphibians (Llusia et al., 2011; Marques et al., 2013), birds (Laiolo \& Tella, 2006; Walcott et al., 2006; Volodin et al., 2008; Klenova et al., 2009) and mammals (marine mammals: Burham et al., 2016; Caruso et al., 2017; primates: Kalan et al., 2016; carnivores: Suter et al., 2017; ungulates: Nelson et al., 2005; Volodin et al., 2013, 2016b; Yen et al., 2013; Enari et al., 2017).

Ungulates are among the most charismatic species of ecosystems. Therefore, management of ungulate populations in conservation areas, tourist areas and buffer zones of state nature reserves represents an actual research task (Bobek et al., 1986; Yen et al., 2013). For Cervidae species, the acoustic monitoring of rutting roaring activities is developing in recent years e.g. for sika deer Cervus nippon Temminck, 1838 (Yen et al., 2013; Enari et al., 2017) and for red deer C. elaphus Linnaeus, 1758 (Volodin et al., 2013, 2016b).

Red deer stags produce impressive high-amplitude vocalisations when compete with each other for hinds in rut period (Clutton-Brock \& Albon, 1979; Reby \& McComb, 2003; Frey et al., 2012; Bocci et al., 2013; Douhard et al., 2013; Volodin et al., 2013, 2015b, 2019; Della Libera et al., 2015; Golosova et al., 2017). Rutting calls reflect male quality (Clutton-Brock \& Albon, 1979; Reby \& McComb, 2003; Charlton et al., 2007) and reproductive potential (Pepin et al., 2001; Briefer et al., 2010). Male rutting vocalisation activate and synchronise ovulation of females (McComb, 1987; Calabrese et al., 2018). Dynamics and duration of stag roaring activity reflect male condition, as stags in a worse body condition end calling earlier (Clutton-Brock \& Albon, 1979). 
Rutting vocal activity is strictly seasonal in all subspecies of red deer inhabiting Europe and Asia (Clutton-Brock \& Albon, 1979; Volodin et al., 2013, 2016b; Golosova et al., 2017). Stag roaring activity has a clear dynamic, indicating rut onset, peak and completion (Bocci et al., 2013; Yen et al., 2013; Volodin et al., 2016b).

Roaring activity is influenced by abiotic factors: time of day, snowfall, temperature and other weather effects (Bocci et al., 2013; Douhard et al., 2013; Volodin et al., 2013, 2015b, 2016 b). In addition, stag roaring is affected by social factors, like animal density/group composition (Volodin et al., 2015a, 2016b) and by management approaches: captive, semi-captive or free-ranging (Golosova et al., 2017). Indices of roaring activity might also depend on the particular site (placement of the acoustic recording device) within the monitored area. However, this site-level effect has not yet been investigated anywhere.

Two native subspecies of Cervus elaphus inhabit the Asian part of Russia: the Siberian wapiti C. e. sibiricus Severtzov, 1873 (Russian name: maral) and the Far-East wapiti C. e. xanthopygus Milne-Edwards, 1867 (Russian name: izubr). These two subspecies are well distinguishable by both genetic markers (Kuznetsova et al., 2012) and by the acoustics of male rutting calls (Volodin et al., 2013; 2015b; 2016a; Golosova et al., 2017). For instance, frequency ranges of male rutting calls are remarkably different between the two subspecies: on average $0.09 \mathrm{kHz}$ for the minimum and on average 0.66 $\mathrm{kHz}$ for the maximum fundamental frequency in Far-East wapiti (Volodin et al., 2015b) and respectively $0.41 \mathrm{kHz}$ and $1.36 \mathrm{kHz}$ in Siberian wapiti (Golosova et al., 2017). At the same time, call duration and organising rutting calls in bouts are similar in both subspecies (Volodin et al., 2013; 2015b; 2016a; Golosova et al., 2017).

For wild-living Siberian wapiti, the dynamic of rutting vocal activity was only investigated for a part of rutting period in the Khakasskiy State Nature Reserve (Volodin et al., 2013). For the farmed and semi-captive Siberian wapiti, the dynamics of rutting vocal activity were investigated throughout the entire rut period (Volodin et al., 2016b). For the Far-East wapiti, the dynamic of rutting vocal activity was only investigated for a part of rut period in a wild-living population of the Ussuriysky State Nature Reserve (Volodin et al., 2015b).
Automated acoustic recording is the most suitable method for estimating the roaring activity of wild-living red deer populations (Volodin et al., 2013, 2015b, 2016b). The automated recording devices can be scheduled for collecting calls throughout the entire rutting period (Volodin et al., 2016b). The aim of this study was to examine the roaring activity of wild-living male Far-East wapiti in the State Nature Reserve «Bolshekhekhtsirsky» (Far East of Russia). In addition, we tested the potential effects of recording site, time of day and temperature on the roaring activity in the course of the rutting period.

\section{Material and Methods}

Study site, subjects and dates of recording

Rutting calls of adult wild-living unmarked male Far-East wapiti were recorded from $25 \mathrm{Au}-$ gust to 21 October 2017 in the State Nature Reserve «Bolshekhekhtsirsky». The State Nature Reserve «Bolshekhekhtsirsky», with a strict regime of environment protection, was founded in 1963 on a $453.4 \mathrm{~km}^{2}$ area about $20 \mathrm{~km}$ south of the city Khabarovsk in the Far East of Russia. According to data of 2017 winter track censuses, the total number of Far-East wapiti at the territory of the State Nature Reserve «Bolshekhekhtsirsky» comprised about 200 individuals (Chronicle of Nature, 2017). This number could vary throughout the year, because the animals freely leave the unfenced territory of the Bolshekhekhtsirsky Reserve for visiting the neighbouring forested areas. No supplementary food is provided to any animal in the State Nature Reserve «Bolshekhekhtsirsky».

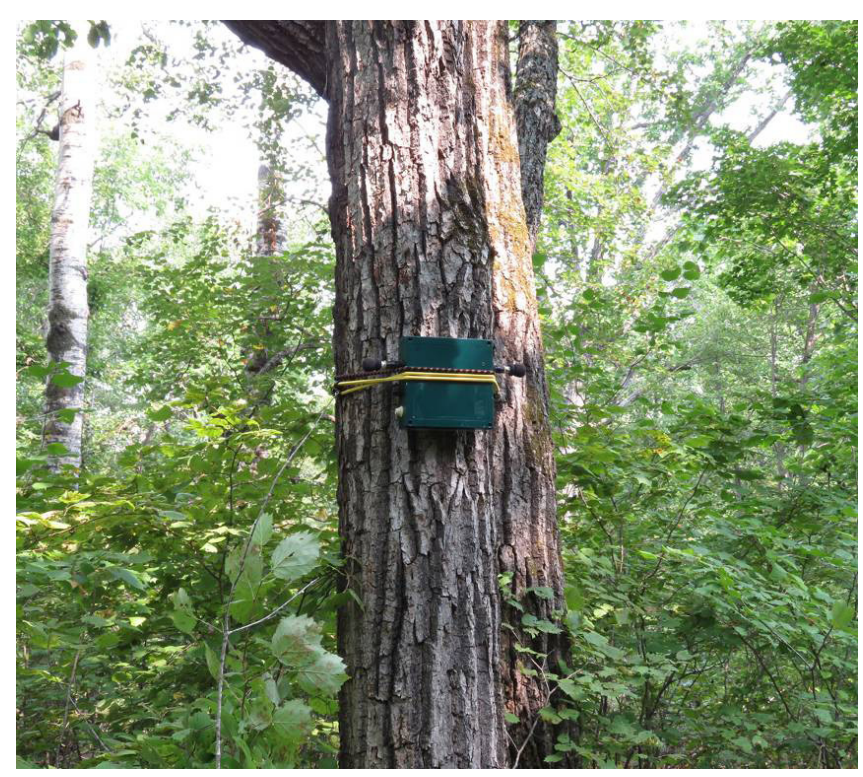

Fig. 1. The device (SongMeter SM2+), mounted on a tree at the State Nature Reserve «Bolshekhekhtsirsky» for the automated acoustic recording of male Far-East wapiti rutting calls. 


\section{Acoustic recording}

For the automated acoustic recording of Far-East wapiti stag rutting calls, we used three devices SongMeter SM2+ (Wildlife Acoustics Inc., Maynard, MA, USA), one in each recording site: "Otstoy» (a cliff above the surrounding forest, $48.14664 \mathrm{~N}, 134.84618 \mathrm{E}$ ), «Mishkin Kluch» (a large clearing in the forest, 48.11356 $\mathrm{N}, 134.85674 \mathrm{E}$ ) and «Odyr» (a cross of two forest roads, $48.11039 \mathrm{~N}, 134.87991 \mathrm{E}$ ). The devices were mounted on trees 2-4 m above the ground. Each device had two omnidirectional microphones, established horizontally at the angle of 180 degrees to each other (Fig. 1). These three recording sites were selected by the staff of the State Nature Reserve «Bolshekhekhtsirsky» as the places of most active rut in previous seasons. All devices remained on their places permanently for the entire rut period. People did not visit them during the rut, to avoid potential animal disturbance.

Each device recorded calls every day, for 58 days in total, in the mode $22.05 \mathrm{kHz}, 16$ bit, stereo. The recording schedule was set at $5 \mathrm{~min}$ and $55 \mathrm{~min}$ pause, $120 \mathrm{~min}$ in total per 24-h cycle, with simultaneous registration of temperature every hour (precision $\pm 1^{\circ} \mathrm{C}$ ) at the start moment of each 5-min recording. The total of 41765 -min digital sound files provided $360 \mathrm{~h}$ of recordings, $120 \mathrm{~h}$ of recording per device.

The minimum distance between the neighbouring devices was $2 \mathrm{~km}$. The devices were set at maximum possible sensitivity and potentially collected all stag rutting calls from the distance of about $1 \mathrm{~km}$. Wapiti rutting calls propagate to a distance up to $1.5 \mathrm{~km}$ (Volodin et al., 2013). Therefore, to exclude even a minor possibility of recording the same calls with two or three devices simultaneously, we de-synchronised the schedule of their work within every hour.

\section{Acoustic analyses}

All sound files were viewed and analysed through Avisoft SASLab Pro software (Avisoft Bioacoustics, Germany, Berlin) main window. The number of calls in each audio file irrespective of their quality was counted (Fig. 2). Some calls were faint and indistinguishable by ear from the background noise, but they were still detectable by spectrograms (Fig. 2). In total, for the three devices we registered 3474 rutting calls (1538 calls at Otstoy, 1159 calls at Mishkin Kluch and 777 calls at Odyr).

To track the rutting vocal activity during the season, we calculated the daily mean call number per hour for each 24-h cycle (as the total number of calls/ day, divided by 24) across 58 days of the recording period. We also calculated the daily mean temperature for each 24-h cycle by 24 registrations, one registration per hour. For evaluating the hourly activity patterns of stag vocalisation, we calculated the mean number of calls/h for each time of day (averaged across the 58 days of recording). In addition, we calculated the hourly mean temperature (averaged by 58 registrations for each time of day across the 58 days of recording). Similar calculations were done for each of the three phases of the rut (see below).
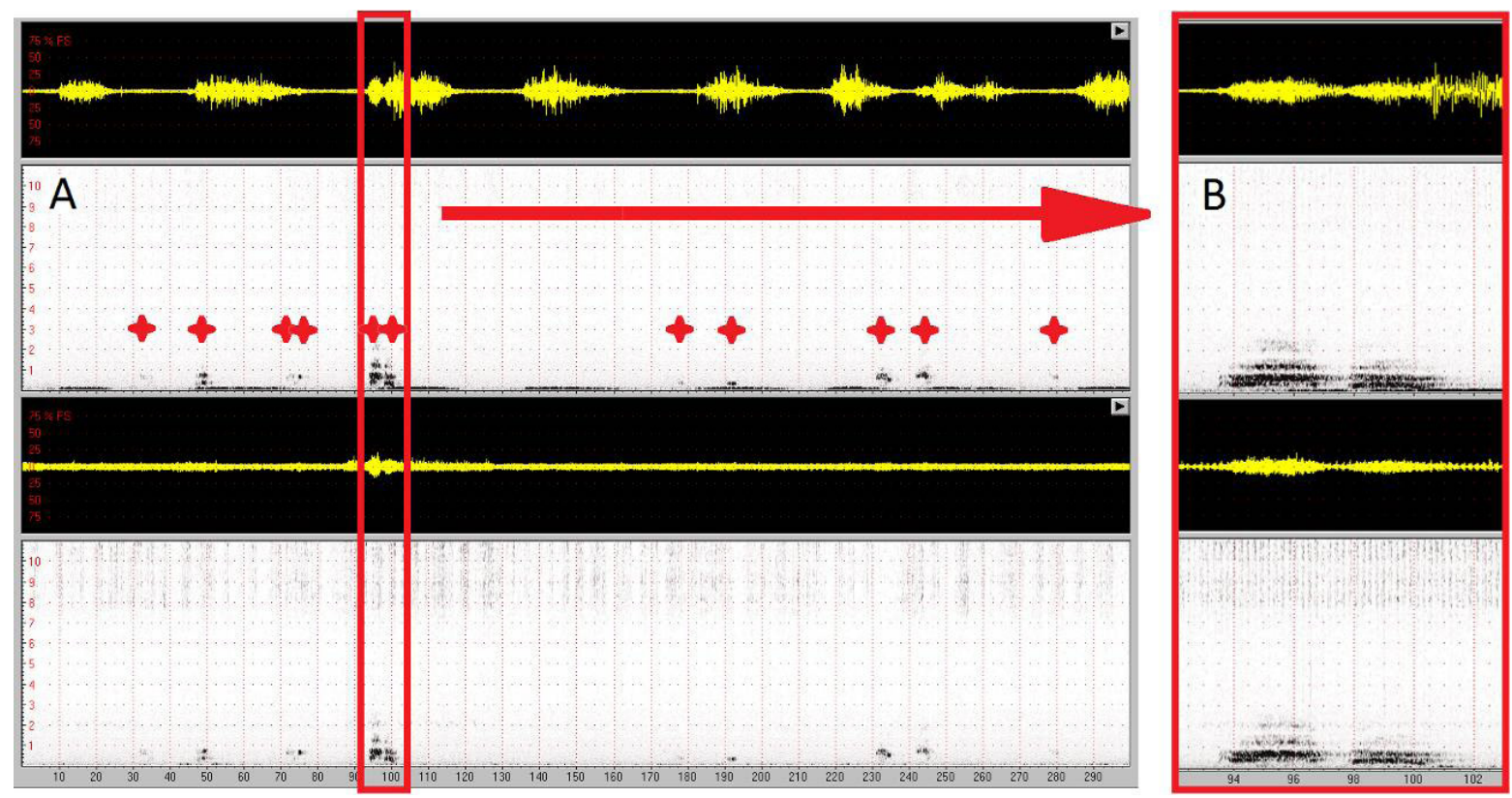

Fig. 2. Visualising stag rutting calls of Far-East wapiti recorded in stereo mode with the automated recording device Song Meter SM2+. Axis X represents time in seconds; axis Y represents frequency in kHz. (A) Spectrogram of one 5-min-long sound file. (B) Expanded spectrogram of the selected fragment with two rutting calls. Stars indicate the rutting calls; the total number of calls is eleven. 


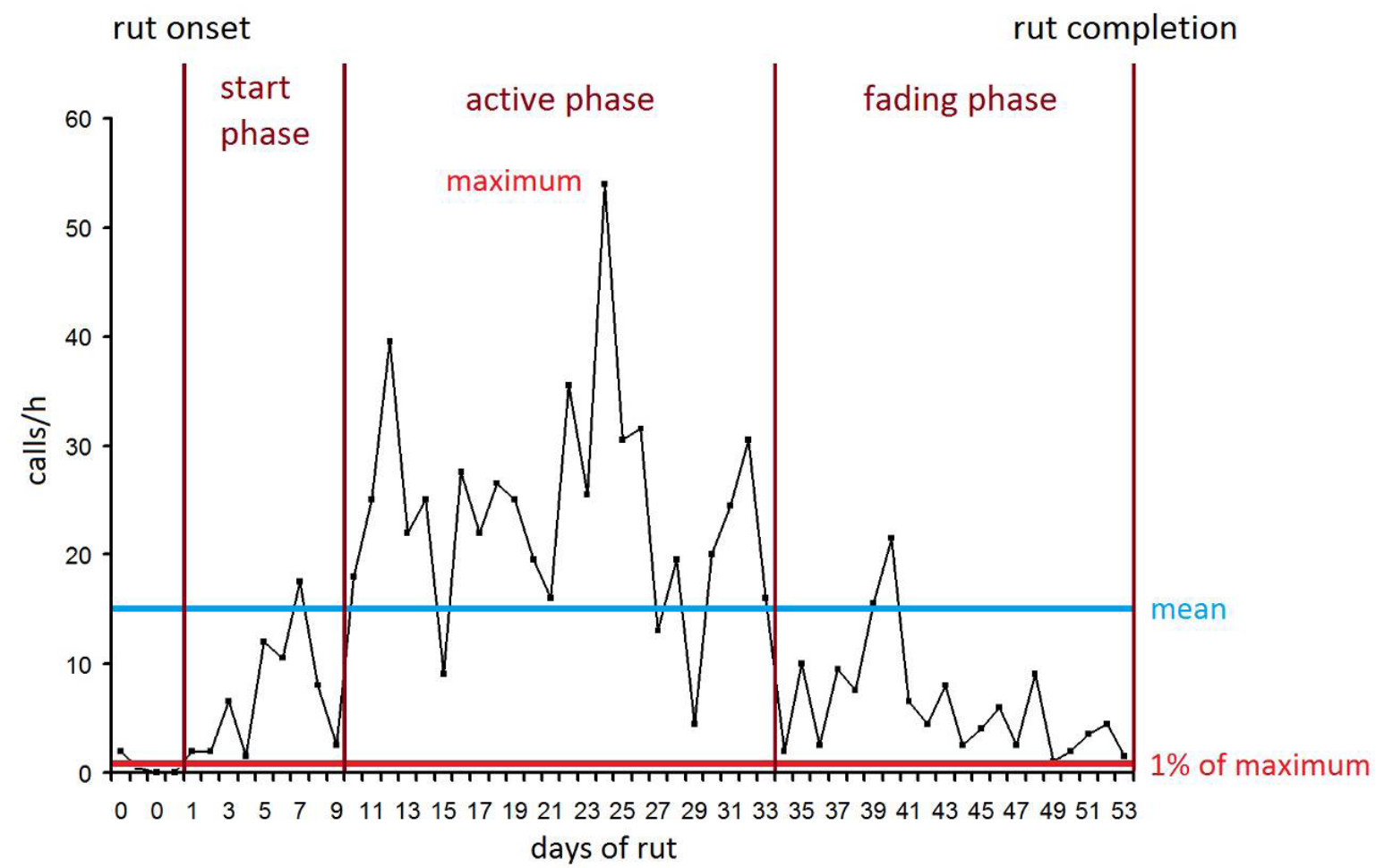

Fig. 3. Subdividing the rut period into three phases: start phase, active phase and fading phase. Maximum: maximum roaring activity; mean: the mean calls/h across rut period from onset to completion.

\section{Subdividing rut period to phases}

To compare the roaring activity among the three recording sites, we developed formal criteria for timing the rut onset and completion on each site (Fig. 3). In addition, we developed formal criteria for subdividing the entire rut period into three phases (start, active and fading). First, we determined, for each site, the day with the maximum roaring activity (calls/h). Then we determined, for each recording site, the days of rut onset and completion as the days when call number/h reached $1 \%$ of the maximum. For each recording site, we calculated the mean call number/h across rut period from onset to completion. We took the period between the day of rut onset and the day with mean call number/h as the start phase. We took the period between the two days with mean call number/h as the active phase. We took the period from the day with mean call number/h to the day of rut completion as the fading phase (Fig. 3).

\section{Statistical analyses}

All statistical analyses were made with STATISTICA v. 8.0 (StatSoft Inc., Tulsa, OK, USA). Means are given as mean $\pm \mathrm{SE}$, all tests were twotailed, and differences were considered significant whenever $p<0.05$. Distributions of 329 parameter values of 462 distributions did not depart from normality (Kolmogorov-Smirnov test, $p>0.05$ ). As parametric ANOVA is relatively robust to departures from normality (Dillon \& Goldstein, 1984), this was not an obstacle to the application of these tests, what allowed us to apply parametric tests.

We applied a one-way ANOVA with Tukey HSD (Honestly Significant Difference) test to compare the roaring activity between recording sites. We used the Pearson's correlation to compare the dynamics of roaring activity between recording sites and between the daily roaring activity and mean temperature during the entire rut period and during the three rut phases. We used the General Linear Mixed Model (GLMM) to estimate the joint effect of temperature, time of day (hourly) and the phase of the rut on the number of calls/h; taking time of day and the phase of the rut as fixed categorical factors and temperature as continual factor.

\section{Results}

Roaring activity in the course of the rut was different in the three recording sites (Fig. 4; Table 1). In each site, the roaring activity occurred at approximately the same calendar dates, from the last days of August to 16-21 October. In each site, the active phase lasted for about three weeks, from 8-9 September to the first days of October. In each site, the active phase and the day with maximum roaring activity were skewed towards the rut onset rather than to the rut completion (Table 1). 


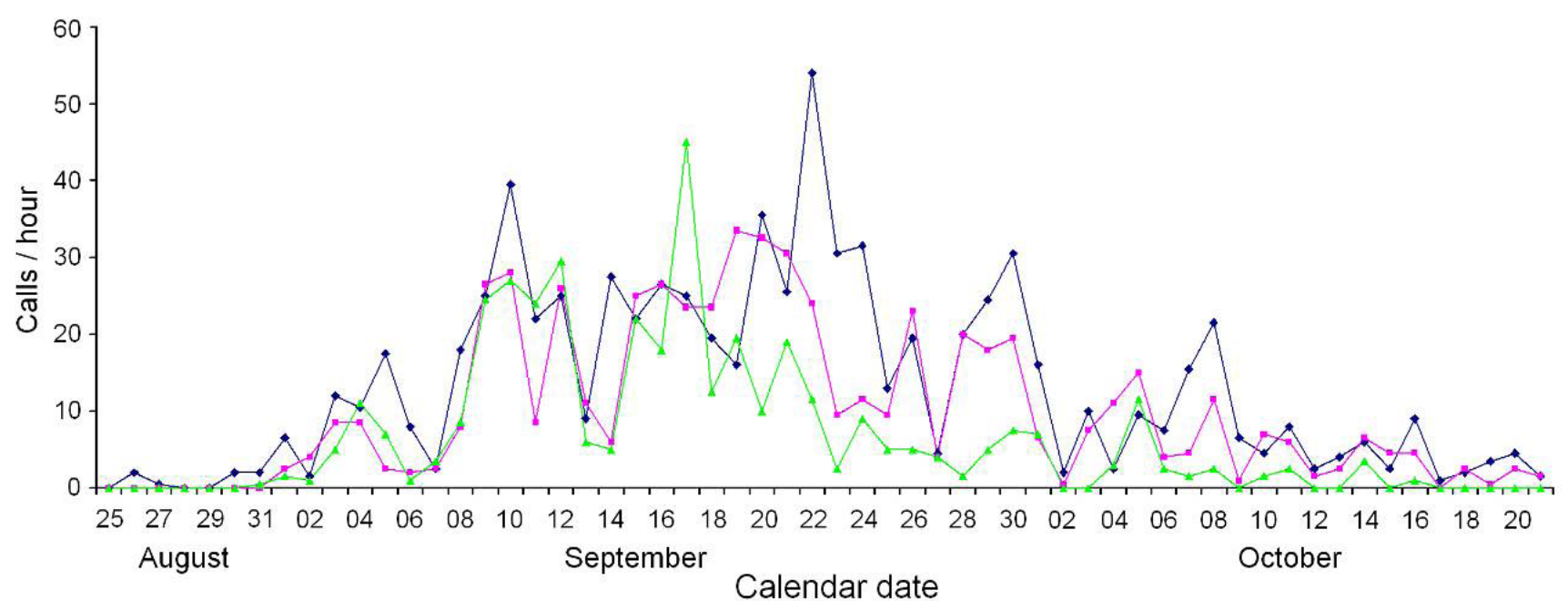

Fig. 4. Graphs by calendar dates of male Far-East wapiti stag roaring activity (in the course of the 58-days recording period during the rut of 2017) at three recording sites: Otstoy (blue rhombs), Mishkin Kluch (red squares) and Odyr (green triangles). Calls/hour: the daily mean call number/h (averaged by 24 digital sound files recorded per $24-\mathrm{h}$ cycle). Rhombs, squares and triangles indicate the mean number of calls/h in each $24-\mathrm{h}$ cycle.

Table 1. Parameter values of roaring activity in the course of rut period of 2017 at three recording sites: Otstoy, Mishkin Kluch and Odyr; and one-way ANOVA results for their comparison between the recording sites. The same superscripts indicate which values did not differ significantly $(p>0.05$, Tukey HSD test). Significant values are labeled in bold

\begin{tabular}{|c|c|c|c|c|}
\hline \multirow{2}{*}{ Parameter } & \multicolumn{3}{|c|}{ Recording site } & \multirow{2}{*}{ ANOVA } \\
\hline & Otstoy & Mishkin Kluch & Odyr & \\
\hline Rut onset (date) & 30.08 .2017 & 01.09 .2017 & 31.08 .2017 & \\
\hline Start of rut active phase (date) & 08.09 .2017 & 09.09.2017 & 08.09.2017 & \\
\hline Roaring maximum (date) & 22.09 .2017 & 19.09.2017 & 17.09.2017 & \\
\hline Start of rut fading phase (date) & 02.10 .2017 & 01.10 .2017 & 29.09.2017 & \\
\hline Rut completion (date) & 21.10 .2017 & 21.10 .2017 & 16.10.2017 & \\
\hline Rut total duration (days) & 53 & 51 & 47 & \\
\hline Rut start phase duration (days) & 9 & 8 & 8 & \\
\hline Rut active phase duration (days) & 24 & 22 & 17 & \\
\hline Rut fading phase duration (days) & 20 & 21 & 22 & \\
\hline Duration to rut maximum (days) & 23 & 18 & 17 & \\
\hline Rut start phase percentage $(\%)$ & 17 & 16 & 17 & \\
\hline Rut active phase percentage $(\%)$ & 45 & 43 & 36 & \\
\hline Rut fading phase percentage (\%) & 38 & 41 & 47 & \\
\hline Percentage to rut maximum (\%) & 43 & 35 & 36 & \\
\hline Maximum roaring activity (calls/h) & 54 & 33.5 & 45 & \\
\hline All-rut mean roaring activity (calls/h) & $14.46 \pm 1.62^{\mathrm{a}}$ & $11.36 \pm 1.39^{\mathrm{a}, \mathrm{b}}$ & $8.27 \pm 1.42^{\mathrm{b}}$ & $F_{2,148}=4.28 ; \boldsymbol{p}=\mathbf{0 . 0 2}$ \\
\hline Start phase mean roaring activity (calls/h) & $6.94 \pm 1.86$ & $4.81 \pm 1.05$ & $3.81 \pm 1.31$ & $F_{2,22}=1.19 ; p=0.32$ \\
\hline Active phase mean roaring activity (calls/h) & $24.17 \pm 2.08$ & $20.00 \pm 1.90$ & $17.26 \pm 2.64$ & $F_{2,60}^{2,2}=2.51 ; p=0.09$ \\
\hline Fading phase mean roaring activity (calls/h) & $6.20 \pm 1.15^{\mathrm{a}}$ & $4.81 \pm 0.87^{\mathrm{a}, \mathrm{b}}$ & $2.93 \pm 0.64^{b}$ & $F_{2.60}=3.37 ; \boldsymbol{p}=\mathbf{0 . 0 4}$ \\
\hline Median roaring activity (calls/h) & 10.5 & 8 & 5 & \\
\hline
\end{tabular}

The mean roaring activity for the entire rut period was the highest at Otstoy and the lowest at Odyr (differences are significant), whereas at Mishkin Kluch it was intermediate, being not significantly different from those in the other two sites (Table 1). At the start phase and at the active phase, the mean roaring activity did not differ between the recording sites. However, at the fading phase, the mean roaring activity was again significantly high- er at Otstoy than at Odyr and displayed the intermediate value at Mishkin Kluch (Table 1).

The rut duration was the longest at Otstoy (53 days), the shortest at Odyr (47 days) and intermediate at Mishkin Kluch (51 days). The duration of the start phase and of the fading phase was approximately the same in the three recording sites, the shortening of rut period at Mishkin Kluch and Odyr was mainly due to the shorter active phase in these sites (Table 1). 
Table 2. Pearson's correlation between the daily roaring activity and the mean temperature per 24-h cycle for the entire rut period and separately for the three rut phases at the three recording sites: Otstoy; Mishkin Kluch and Odyr. Significant values are labeled in bold

\begin{tabular}{llll}
\hline \multirow{2}{*}{ Rut phase } & \multicolumn{1}{c}{ Otstoy } & \multicolumn{1}{c}{ Recording site } & \multicolumn{1}{c}{ Odyr } \\
\cline { 2 - 4 } All rut & $r=0.48 ; \boldsymbol{p}<\mathbf{0 . 0 0 1} ; n=53$ & $r=0.35 ; \boldsymbol{p}=\mathbf{0 . 0 1} ; n=51$ & $r=0.38 ; \boldsymbol{p}=\mathbf{0 . 0 0 8} ; n=47$ \\
Start phase & $r=0.47 ; p=0.20 ; n=9$ & $r=-0.17 ; p=0.69 ; n=8$ & $r=0.46 ; p=0.25 ; n=8$ \\
Active phase & $r=0.40 ; p=0.052 ; n=24$ & $r=0.16 ; p=0.49 ; n=22$ & $r=-0.33 ; p=0.20 ; n=17$ \\
Fading phase & $r=0.49 ; \boldsymbol{p}=\mathbf{0 . 0 3} ; n=20$ & $r=0.10 ; p=0.66 ; n=21$ & $r=0.19 ; p=0.39 ; n=22$ \\
\hline
\end{tabular}

We found significant positive correlations of roaring activity among all the three recording sites. We calculated Pearson's correlations for the 46-day part of the rut period, from $1^{\text {st }}$ September (rut onset at Mishkin Kluch) to $16^{\text {th }}$ October (rut completion at Odyr). Stronger correlations were found between Otstoy and Mishkin Kluch $(r=0.694, p<0.001)$ and between Mishkin Kluch and Odyr $(r=0.697$, $p<0.001$ ), whereas a weaker correlation was found between Otstoy and Odyr $(r=0.528, p<0.001)$.

For the entire rut period, the daily roaring activity showed a significant positive correlation with the mean temperature per 24-h cycle in all the three recording sites (Table 2). However, separately for the start phase and for the active phase, we did not find the significant correlation between the daily roaring activity and daily mean temperature. Separately for the fading phase, the significant positive correlation between the daily roaring activity and daily mean temperature was found at Otstoy, but not at Mishkin Kluch or Odyr. Therefore, the effect of temperature on the daily roaring activity lacked rather than presented; a positive correlation observed for the entire rut period could be due to the effect of the large number of days included in the analysis.

At all the three recording sites, the mean number of calls was related to time of day (Fig. 5). At any site, the roaring activity was the highest between 03:00 and 06:00 a.m. and nearly lacked between 10:00 a.m. and 6:00 p.m. At any site, the number of calls/h steadily increased from 8:00 p.m. to 03:00 a.m. to maximum and then rapidly decreased from $06: 00$ to $09: 00$ a.m. to the minimum value (Fig. 5). The hourly number of calls/h significantly negatively correlated with temperature at each recording site: Otstoy $(r=-0.92 ; p<0.001 ; n=24)$, Mishkin Kluch $(r=-0.91 ; p<0.001 ; n=24)$ and $\operatorname{Odyr}(r=-0.87 ; p<0.001 ; n=24)$.
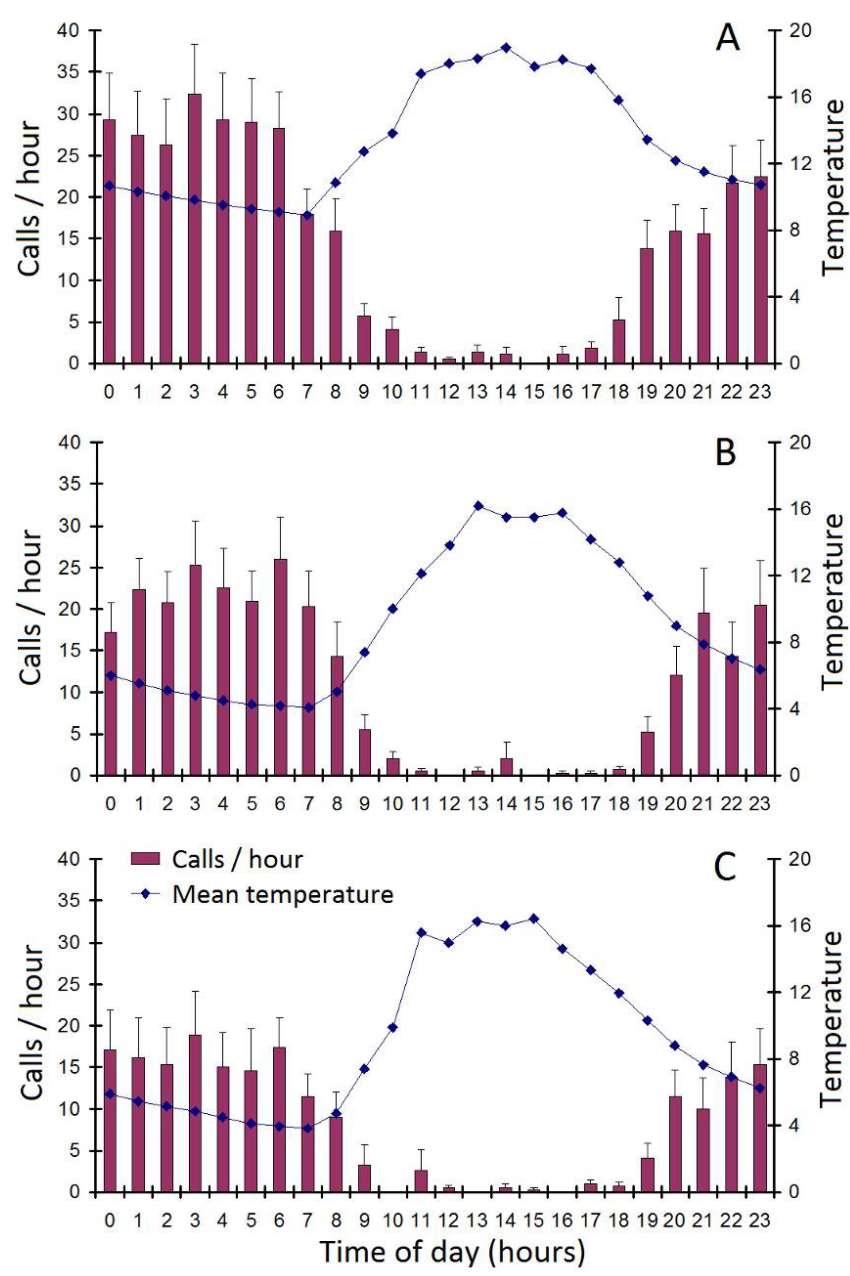

Fig. 5. Time of day (hourly) graphs of male Far-East wapiti roaring activity and of the mean hourly temperature in three sites of acoustic recording: (A) Otstoy; (B) Mishkin Kluch; (C) Odyr. Calls/h: the mean number of calls per time of day (averaged across the 58 days of recording); mean temperature: the hourly mean temperature (averaged by 58 registrations for each time of day across the 58 days of recording); whiskers indicate SE.

Table 3. Effects of the rut phase, time of day (hourly) and temperature on the roaring activity of male Far-East wapiti in the course of the rut period at three recording sites: Otstoy, Mishkin Kluch and Odyr. Significant values are labeled in bold

\begin{tabular}{|c|c|c|c|}
\hline \multirow{2}{*}{ Factor } & \multicolumn{3}{|c|}{ Recording site } \\
\hline & Otstoy & Mishkin Kluch & Odyr \\
\hline Rut phase & $F_{2,1245}=62.49 ; \boldsymbol{p}<\mathbf{0 . 0 0 1}$ & $F_{2,1197}=65.96 ; \boldsymbol{p}<\mathbf{0 . 0 0 1}$ & $F_{2,1101}=52.35 ; \boldsymbol{p}<\mathbf{0 . 0 0 1}$ \\
\hline Time of day & $F_{23,1245}=10.44 ; \boldsymbol{p}<\mathbf{0 . 0 0 1}$ & $F_{23,1197}=3.98 ; \boldsymbol{p}<\mathbf{0 . 0 0 1}$ & $F_{23,1101}=2.33 ; \boldsymbol{p}<\mathbf{0 . 0 0 1}$ \\
\hline Temperature & $F_{1,1245}=10.65 ; \boldsymbol{p}=\mathbf{0 . 0 0 1}$ & $F_{1,1197}=4.27 ; \boldsymbol{p}=\mathbf{0 . 0 4}$ & $F_{1,1101}=2.31 ; p=0.13$ \\
\hline
\end{tabular}


Table 4. Effects of time of day and of hourly temperature on roaring activity of male Far-East wapiti at different phases of the rut in the course of the rut period at three recording sites: Otstoy, Mishkin Kluch and Odyr. Significant values are labeled in bold

\begin{tabular}{lllll}
\hline \multirow{2}{*}{ Rut phase } & \multicolumn{1}{c}{ Factors } & \multicolumn{1}{c}{ Recording site } \\
\cline { 3 - 5 } & & \multicolumn{1}{c}{ Otstoy } & \multicolumn{1}{c}{ Mishkin Kluch } \\
\hline \multirow{2}{*}{ Start } & Time of day & $F_{23,191}=1.86 ; \boldsymbol{p}=\mathbf{0 . 0 1}$ & $F_{23,167}=1.38 ; \boldsymbol{p}=0.12$ & $F_{23,167}=1.78 ; \boldsymbol{p}=\mathbf{0 . 0 2}$ \\
& Temperature & $F_{1,191}=2.90 ; \boldsymbol{p}=0.09$ & $F_{1,167}=7.00 ; \boldsymbol{p}=\mathbf{0 . 0 0 9}$ & $F_{1,167}=0.95 ; p=0.33$ \\
\multirow{2}{*}{ Active } & Time of day & $F_{23,551}=7.76 ; \boldsymbol{p}<\mathbf{0 . 0 0 1}$ & $F_{23,503}=3.24 ; \boldsymbol{p}<\mathbf{0 . 0 0 1}$ & $F_{23,383}=1.22 ; p=0.22$ \\
& Temperature & $F_{1,551}=1.55 ; \boldsymbol{p}=0.21$ & $F_{1,503}=1.75 ; \boldsymbol{p}=0.19$ & $F_{1,383}=9.67 ; \boldsymbol{p}=\mathbf{0 . 0 0 2}$ \\
\multirow{2}{*}{ Fading } & Time of day & $F_{23,455}=3.33 ; \boldsymbol{p}<\mathbf{0 . 0 0 1}$ & $F_{23,479}=1.77 ; \boldsymbol{p}=\mathbf{0 . 0 2}$ & $F_{23,503}=1.66 ; \boldsymbol{p}=\mathbf{0 . 0 3}$ \\
& Temperature & $F_{1,455}=10.25 ; \boldsymbol{p}=\mathbf{0 . 0 0 1}$ & $F_{1,479}=2.44 ; \boldsymbol{p}=0.12$ & $F_{1,503}=0.01 ; \boldsymbol{p}=0.95$ \\
\hline
\end{tabular}

We estimated the joint effect of temperature, time of day and rut phase on roaring activity (number of calls/h) by using GLMM (Table 3). The rut phase, time of day and temperature significantly influenced the roaring activity. The only exclusion was the lack of temperature effect at Odyr. Based on Fisher's criteria, the rut phase had a stronger effect on roaring activity compared to the effects of either time of day or temperature (Table 3).

Because of the found strong effect of the rut phase on the roaring activity, we analysed the effect of time of day and temperature on the number of calls $/ \mathrm{h}$ in each phase of the rut separately (Table 4). Time of day influenced the number of calls/h in two recording sites at the start phase, in two recording sites at the active phase and in all the three recording sites at the fading phase. The factor temperature influenced the number of calls/h in one recording site at the start phase, in one recording site at the active phase and in one recording site at the fading phase (Table 4).

\section{Discussion}

Factors affecting roaring activity

This study of male Far-East wapiti roaring activity demonstrated that in each of the three recording sites the rutting vocal activity displayed three phases: start phase, active phase and fading phase. Although the roaring activity displayed a positive correlation between sites, the actual values of the mean number of calls/h differed between the sites. This indicates the different use of the sites by male wapiti during the rut. In all the three recording sites, the roaring activity was related to time of day, and was the highest between 03:00 and 06:00 a.m. and nearly lacked between 10:00 a.m. and 18:00 p.m.

Overall, these results point a way for optimising and minimising the effort for further conducting the passive acoustic monitoring of the Far-East wapiti population in the State Nature Reserve «Bolshekhekhtsirsky». We suggest using 1) a single recording site, preferentially Otstoy, displaying the highest male roaring activity, 2) only the active rut phase, approximately between 08 September and 02 October, and 3 ) only nighttime, between 03:00 and 06:00 a.m.. This restricted recording schedule of passive acoustic monitoring appears to be sufficient for providing representative data about the population rutting activity in subsequent rutting seasons.

\section{Inter-population comparison}

Further research is necessary to understand whether these suggestions can be expanded to other populations of the Far-East wapiti and other conservation areas. However, we can compare data of this study with available (although limited) data on dynamics of rutting vocal activity of the Far-East wapiti, obtained in the course of 15-day recordings, conducted at the territory of the State Nature Reserve «Ussuriysky» (http://www.ussuriysky.ru/) in rut period of 2014. The site of passive acoustic monitoring at the State Nature Reserve «Ussuriysky» (43.65305 N, $132.64388 \mathrm{E})$ was located at a distance of about $600 \mathrm{~km}$ from the State Nature Reserve «Bolshekhekhtsirsky». The territory of the State Nature Reserve «Ussuriysky» $\left(404.32 \mathrm{~km}^{2}\right)$ is comparable in size to that of the State Nature Reserve «Bolshekhekhtsirsky» $\left(453.40 \mathrm{~km}^{2}\right)$. The population numbers of Far-East wapiti are also comparable between the two state nature reserves, about 200 individuals at the State Nature Reserve «Bolshekhekhtsirsky (Chronicle of Nature, 2017) and about 150 individuals at the State Nature Reserve «Ussuriysky»" (Litvinov, 2008). Both state nature reserves have a strict conservation regime, without providing any supplementary feeding to animals, ensuring their natural distribution over the territory. At both state nature reserves, wapiti are under press of the same set of predators: the Amur tiger Panthera tigris altaica Temminck, 1844, the Brown bear Ursus arctos Linnaeus, 1758 and the Asian black bear 
Ursus thibetanus G. (Baron) Cuvier, 1823. The only noticeable difference between populations is the presence of another species of the genus Cervus (sika deer) at the State Nature Reserve «Ussuriysky» (Litvinov, 2008; Volodin et al., 2015b).

In both state nature reserves, the roaring maximum was observed at night time, between 03:00 and 06:00 a.m., whereas the roars lacked between 10:00 a.m. and 6:00 p.m. at the State Nature Reserve «Bolshekhekhtsirsky» and between 2:00 p.m. and 5:00 p.m at the State Nature Reserve «Ussuriysky» (Volodin et al., 2015b). In both state nature reserves, temperature significantly influenced the hourly roaring activity. Similarly to the State Nature Reserve «Bolshekhekhtsirsky», this effect of temperature was negative also at the State $\mathrm{Na}-$ ture Reserve «Ussuriysky» $(r=-0.79, p<0.001$, $n=24$; Volodin et al., 2015b).

\section{Implications}

Stag roaring activity can be used for population managing purposes on farms (Volodin et al., 2016b), in hunting facilities (Douhard et al., 2013) and at conservation areas (Volodin et al., 2013, $2015 b$ ). Stag roaring activity over the rut period might help in estimating the state of the given population in comparison with other populations of red deer (Carranza et al., 1990; Smith-Flueck \& Flueck, 2006; Volodin et al., 2016b) and potentially for tracking the changes in the state of populations over time at local level and in frames of the purposeful study of the mammalian fauna of Russia using public databases (Lissovsky et al., 2018).

The impressive rutting roaring of Cervidae species can be considered as an important seasonal key marker of the acoustic landscapes: soundscapes, in addition to the insect, anuran or bird chorus (insects: Jeliazkov et al., 2016; Desjonquères et al., 2018; birds: Gasc et al., 2017; anurans and other taxa: Ferreira et al., 2018). These key markers are necessary for creating false colour spectrograms for applying the modern ecoacoustic approach at conservation areas (Ferreira et al., 2018; Lillis et al., 2018; Sugai et al., 2018; Towsey et al., 2018). Devices used for recording Far-East wapiti, simultaneously record vocalisation of other animals and abiotic noise, thus providing potential material for further monitoring of the ecoacoustic landscapes of the conservation areas (Sugai et al., 2018). The ecoacoustic approach, based on recent integration of ecology and bioacoustics, is a new scientific discipline aimed on analyses of big data, collected by using automated recording devices for quantitative estimating biodi- versity and landscape sustainability (Farina \& Gage, 2017; Towsey et al., 2018).

\section{Limitations}

Passive acoustic monitoring is not well suitable for estimating population size, although roaring counts are often used as indices of red deer abundance (Douhard et al., 2013). An important limitation on acoustic monitoring of red deer and wapiti populations is that individuals cannot be identified from the automated acoustic recordings. Probably, this limitation of impossibility discriminating individuals by their calls will be overcome by further research of individual vocal identity in different subspecies of Cervus elaphus. However, at the current stage of knowledge, the number of individual callers cannot be counted this way and only a relative level of acoustic activity can be monitored at the given recording site from year to year. So, for censuses, other methods: pellet counts, camera traps etc. should be used (Pfeffer et al., 2017), in addition to the estimating population number by stag rutting roars.

\section{Conclusions}

Passive acoustic monitoring of male FarEast wapiti provided data about roaring activity throughout the rut at sites of the most active rut in the State Nature Reserve «Bolshekhekhtsirsky» (Russia). Study site, temperature and time of day affected the roaring activity of male Far-East wapiti. The obtained data about dynamics of rutting roaring activity can be expanded to other native wild-living populations of Far-East wapiti, inhabiting Protected Areas with strict conservation regime without providing supplementary food. Further research of individual vocal identity in different subspecies of Cervus elaphus is necessary to overcome the limitations of the method for population censuses because of the impossibility discriminating individuals by their calls.

\section{Acknowledgements}

We thank the staff of the State Nature Reserve «Bolshekhekhtsirsky» for their help and support. We thank O.V. Sibiryakova for help with data transport from the State Nature Reserve «Bolshekhekhtsirsky». Data for this study were collected in accordance with the Guidelines for the Use of Animals in Research (Animal Behaviour, 2006, 71: 245-253) and with guidelines of the staff of the State Nature Reserve «Bolshekhekhtsirsky» regarding animal welfare. No animal has suffered somehow due to the data collection. The study was supported by the Russian Foundation for Basic Research, grant 19-04-00133 (to IAV and EVV). 


\section{References}

Bobek B., Perzanowski K., Zielinski J. 1986. Red deer population census in mountains: testing of an alternative method. Acta Theriologica 31: 424-431. DOI: 10.4098/ AT.arch.86-39

Bocci A., Telford M., Laiolo P. 2013. Determinants of the acoustic behaviour of red deer during breeding in a wild alpine population, and implications for species survey. Ethology Ecology and Evolution 25(1): 52-69. DOI: 10.1080/03949370.2012.705331

Briefer E., Vannoni E., McElligott A.G. 2010. Quality prevails over identity in the sexually selected vocalisations of an ageing mammal. BMC Biology 8: 35. DOI: 10.1186/1741-7007-8-35

Burham R.E., Palm R.S, Duffus D.A., Mouy X., Riera A. 2016. The combined use of visual and acoustic data collection techniques for winter killer whale (Orcinus orca) observations. Global Ecology and Conservation 8: 24-30. DOI: 10.1016/j.gecco.2016.08.001

Calabrese J.M., Moss Clay A., Estes R.D., Thompson K.V., Monfort S.L. 2018. Male rutting calls synchronize reproduction in Serengeti wildebeest. Scientific Reports 8(1): 10202. DOI: 10.1038/s41598-018-28307-y

Carranza J., Alvarez F., Redondo T. 1990. Territoriality as a mating strategy in Red deer. Animal Behaviour 40(1): 79-88. DOI: 10.1016/S0003-3472(05)80667-0

Caruso F., Alonge G., Bellia G., De Domenico E., Grammauta R., Larosa G., Mazzola S., Riccobene G., Pavan G., Papale E., Pellegrino C., Pulvirenti S., Sciacca V., Simeone F., Speziale F., Viola S., Buscaino G. 2017. Long-term monitoring of dolphin biosonar activity in deep pelagic waters of the Mediterranean Sea. Scientific Reports 7: 4321. DOI: 10.1038/s41598-017-04608-6

Charlton B.D., Reby D., McComb K. 2007. Female red deer prefer the roars of larger males. Biology Letters 3(4): 382-385. DOI: 10.1098/rsbl.2007.0244

Clutton-Brock T.H., Albon S.D. 1979. The roaring of red deer and the evolution of honest advertising. Behaviour 69(3): 145-170. DOI: 10.1163/156853979X00449

Della Libera M., Passilongo D., Reby D. 2015. The acoustics of male rutting roars in the endangered population of Mesola red deer Cervus elaphus italicus. Mammalian Biology 80: 395-400. DOI: 10.1016/j.mambio.2015.05.001

Desjonquères C., Rybak F., Ulloa J.S., Kempf A., Hen A.B., Sueur J. 2018. Monitoring the acoustic activity of an aquatic insect population in relation to temperature, vegetation and noise. Freshwater Biology. DOI: 10.1111/fwb.13171

Dillon W.R., Goldstein M. 1984. Multivariate analysis: methods and applications. New York: Wiley. 608 p.

Douhard M., Bonenfant C., Gaillard J.-M., Hamann J.-L., Jacques M.G. 2013. Roaring counts are not suitable for the monitoring of red deer Cervus elaphus population abundance. Wildlife Biology 19(1): 94-101. DOI: 10.2981/12-037

Enari H., Enari H., Okuda K., Yoshita M., Kuno T., Okuda K. 2017. Feasibility assessment of active and pas- sive acoustic monitoring of sika deer populations. Ecological Indicators 79: 155-162. DOI: 10.1016/j. ecolind.2017.04.004

Farina A., Gage S.H. (Eds.). 2017. Ecoacoustics. The ecological role of sounds. Oxford, UK: Wiley. 352 p.

Ferreira L.M., Oliveira E.G., Lopes L.C., Brito M.R., Baumgarten J., Rodrigues F.H., Renata S. Sousa-Lima R.S. 2018. What do insects, anurans, birds, and mammals have to say about soundscape indices in a tropical savanna. Journal of Ecoacoustics 2: PVH6YZ. DOI: 10.22261/JEA.PVH6YZ

Frey R., Volodin I., Volodina E., Carranza J., Torres-Porras J. 2012. Vocal anatomy, tongue protrusion behaviour and the acoustics of rutting roars in free-ranging Iberian red deer stags (Cervus elaphus hispanicus). Journal of Anatomy 220(3): 271-292. DOI: 10.1111/j.14697580.2011.01467.x

Gasc A., Francomano D., Dunning J.B., Pijanowski B.C. 2017. Future directions for soundscape ecology: The importance of ornithological contributions. Auk 134(1): 215-228. DOI: 10.1642/AUK-16-124.1

Golosova O.S., Volodin I.A., Isaeva I.L., Volodina E.V. 2017. Effects of free-ranging, semi-captive and captive management on the acoustics of male rutting calls in Siberian wapiti Cervus elaphus sibiricus. Mammal Research 62(4): 387-396. DOI: 10.1007/s13364-017-0322-4

Jeliazkov A., Bas Y., Kerbiriou C., Julien J.-F., Penone C., Le Viol I. 2016. Large-scale semi-automated acoustic monitoring allows to detect temporal decline of bushcrickets. Global Ecology and Conservation 6: 208-218. DOI: 10.1016/j.gecco.2016.02.008

Kalan A.K., Piel A.K., Mundry R., Wittig R.M., Boesch C., Kühl H.S. 2016. Passive acoustic monitoring reveals group ranging and territory use: a case study of wild chimpanzees (Pan troglodytes). Frontiers in Zoology 13(1): 34. DOI: 10.1186/s12983-016-0167-8

Klenova A.V., Volodin I.A., Volodina E.V. 2009. Examination of pair-duet stability to promote long-term monitoring of the endangered red-crowned crane (Grus japonensis). Journal of Ethology 27(3): 401-406. DOI: 10.1007/s10164-008-0133-9

Kuznetsova M.V., Danilkin A.A., Kholodova M.V. 2012. Phylogeography of red deer (Cervus elaphus): Analysis of mtDNA cytochrome b polymorphism. Biology Bulletin 39(4): 323-330. DOI: 10.1134/S1062359012040048

Laiolo P., Tella J.L. 2006. Landscape bioacoustics allow detection of the effects of habitat patchiness on population structure. Ecology 87(5): 1203-1214. DOI: $10.1890 / 0012-9658$

Chronicle of Nature. 2017. Number of mammals. In: Chronicle of Nature of State Nature Reserve "Bolshekhekhtsirsky» 48: 180-184. [In Russian]

Lillis A., Caruso F., Mooney T.A., Llopiz J., Bohnenstiehl D., Eggleston D.B. 2018. Drifting hydrophones as an ecologically meaningful approach to underwater soundscape measurement in coastal benthic habitats. Journal of Ecoacoustics 2: STBDH1. DOI: 10.22261/JEA.STBDH1

Lissovsky A.A., Sheftel B.I., Stakheev V.V., Ermakov O.A., Smirnov D.G., Glazov D.M., Strelnikov D.P., Ekonomov A.V., Titov S.V., Obolenskaya E.V., Kozlov Y.A., 
Saveljev A.P. 2018. Creating an integrated information system for the analysis of mammalian fauna in the Russian Federation and the preliminary results of this information system. Russian Journal of Theriology 17(2): 85-90. DOI: 10.15298/rusjtheriol.17.2.04

Litvinov M.N. 2008. Peculiarities of ruminant fauna development at the Nature Reserve «Ussuriysky». Animal and Plant World of Far East 11: 127-131. [In Russian]

Llusia D., Marquez R., Bowker R. 2011. Terrestrial sound monitoring systems, a methodology for quantitative calibration. Bioacoustics 20(3): 277-286. DOI: 10.1080/09524622.2011.9753651

Marques T.A., Thomas L., Martin S.W., Mellinger D.K., Ward J.A., Moretti D.J., Harris D., Tyack P.L. 2013. Estimating animal population density using passive acoustics. Biological Review 88(2): 287-309. DOI: 10.1111/brv.12001

McComb K. 1987. Roaring by red deer stags advances the date of oestrus in hinds. Nature 330(6149): 648-649. DOI: $10.1038 / 330648 \mathrm{a} 0$

Nelson D.E., Alkon P.U., Krausman P.R. 2005. Using acoustic telemetry to monitor foraging by penned mule deer. Wildlife Society Bulletin 33(2): 624-632. DOI: $10.2307 / 3785090$

Obrist M.K., Pavan G., Sueur J., Riede K., Llusia D., Marquez R. 2010. Bioacoustics approaches in biodiversity inventories. In: J. Eymann, J. Degreef, C. Häuser, J.C. Monje, Y. Samyn, D. VandenSpiegel (Eds.): Manual on Field Recording Techniques and Protocols for All Taxa Biodiversity Inventories and Monitoring. Vol. 8(1). Brussels: Abc Taxa. P. 68-99.

Pepin D., Cargnelutti B., Gonzalez G., Joachim J., Reby D. 2001. Diurnal and seasonal variations of roaring activity of farmed red deer stags. Applied Animal Behaviour Science 74(3): 233-239. DOI: 10.1016/S01681591(01)00172-1

Pfeffer S.E., Spitzer R, Allen M.A., Hofmeester T.R., Ericsson G., Widemo F., Singh N.J., Cromsigt J.P.G.M. 2017. Pictures or pellets? Comparing camera trapping and dung counts as methods for estimating population densities of ungulates. Remote Sensing in Ecology and Conservation 4: 173-183. DOI: 10.1002/rse2.67

Reby D., McComb K. 2003. Anatomical constraints generate honesty: acoustic cues to age and weight in the roars of red deer stags. Animal Behaviour 65(3): 519-530. DOI: 10.1006/anbe.2003.2078

Setyawan E., Sianipar A.B., Erdmann M.V., Fischer A.M., Haddy J.A., Beale C.S., Lewis S.A., Mambrasar R. 2018. Site fidelity and movement patterns of reef manta rays (Mobula alfredi: Mobulidae) using passive acoustic telemetry in Northern Raja Ampat, Indonesia. Nature Conservation Research 3(4): 17-31. DOI: 10.24189/ ncr.2018.043

Smith-Flueck J.M., Flueck W.T. 2006. Defense of territories by rutting red deer stags, Cervus elaphus, in Patagonia, Argentina. In: L. Bartoš, A. Dušek, R. Kotrba, J. BartošováVíchová (Eds.): Advances in Deer Biology. Praha: Research Institute of Animal Production. P. 174-178.
Sugai L.S.M., Silva T.S.F., Ribeiro J.W. JR., Llusia D. 2018. Terrestrial passive acoustic monitoring: review and perspectives. BioScience 69(1): 15-25. DOI:10.1093/biosci/biy147

Suter S.M., Giordano M., Nietlispach S., Apollonio M., Passilongo D. 2017. Non-invasive acoustic detection of wolves. Bioacoustics 26: 237-248. DOI: 10.1080/09524622.2016.1260052

Towsey M., Znidersic E., Broken-Brow J., Indraswari K., Watson D. M., Phillips Y., Truskinger A., Roe P. 2018. Long-duration, false-colour spectrograms for detecting species in large audio datasets. Journal of Ecoacoustics 2: IUSWUI. DOI: 10.22261/JEA.IUSWUI

Volodin I.A., Klenova A.V., Volodina E.V. 2008. Modelling bioacoustical monitoring through years with captive population of the red-breasted goose. Casarca 11(1): 22-46.

Volodin I.A., Volodina E.V., Frey R., Maymanakova I.L. 2013. Vocal activity and acoustic structure of the rutting calls of Siberian wapiti (Cervus elaphus sibiricus) and their imitation with a hunting luring instrument. Russian Journal of Theriology 12(2): 99-106. DOI: 10.15298/rusjtheriol.12D.2.06

Volodin I.A., Matrosova V.A., Volodina E.V., Garcia A.J., Gallego L., Márquez R., Llusia D., Beltrán J.F., Landete-Castillejos T. 2015a. Sex and age-class differences in calls of Iberian red deer during the rut: reversed sex dimorphism of pitch and contrasting roars from farmed and wild stags. Acta Ethologica 18(1): 19-29. DOI: $10.1007 / \mathrm{s} 10211-013-0179-8$

Volodin I.A., Volodina E.V., Sibiryakova O.V., Naidenko S.V., Hernandez-Blanco J.A., Litvinov M.N., Rozhnov V.V. 2015b. Vocal activity and the acoustic structure of rutting calls in red deer in the Russian Far East. Doklady Biological Science 462(1): 144-147. DOI: 10.1134/ S0012496615030114

Volodin I.A., Sibiryakova O.V., Volodina E.V. 2016a. Sex and age-class differences in calls of Siberian wapiti Cervus elaphus sibiricus. Mammalian Biology 81(1): 10-20. DOI: 10.1016/j.mambio.2015.09.002

Volodin I.A., Volodina E.V., Golosova O.S. 2016b. Automated monitoring of vocal rutting activity in red deer (Cervus elaphus). Russian Journal of Theriology 15(2): 91-99. DOI: 10.15298/rusjtheriol.15.2.03

Volodin I.A., Nahlik A., Tari T., Frey R., Volodina E.V. 2019. Rutting roars in native Pannonian red deer of Southern Hungary and the evidence of acoustic divergence of male sexual vocalization between Eastern and Western European red deer (Cervus elaphus). Mammalian Biology 94: 54-65. DOI: 10.1016/j.mambio.2018.10.009

Walcott C., Mager J.N., Piper W. 2006. Changing territories, changing tunes: male loons, Gavia immer, change their vocalizations when they change territories. Animal Behaviour 71(3): 673-683. DOI: 10.1016/j.anbehav.2005.07.011

Yen S.-C., Shieh B.-S., Wang Y.-T., Wang Y. 2013. Rutting vocalizations of Formosan sika deer Cervus nippon taiouanus - Acoustic structure, seasonal and diurnal variations, and individuality. Zoological Science 30(12): 1025-1031. DOI: 10.2108/zsj.30.1025 


\title{
ПАССИВНЫЙ АКУСТИЧЕСКИЙ МОНИТОРИНГ ГОННОГО РЕВА ИЗЮБРЯ CERVUS ELAPHUS XANTHOPYGUS НА ДАЛЬНЕМ ВОСТОКЕ РОССИИ: ОЦЕНКА ВЛИЯНИЯ ТОЧКИ ЗАПИСИ, ТЕМПЕРАТУРЫ И ВРЕМЕНИ СУТОК
}

\author{
И. Ю. Русин ${ }^{1}$, И. А. Володин ${ }^{1,2, *}$, Р. С. Андронова ${ }^{3}$, Е. В. Володина ${ }^{2}$ \\ ${ }^{1}$ Московский государственный университет имени М.В. Ломоносова, Россия \\ ${ }^{2}$ Московский зоопарк, Россия \\ ${ }^{3}$ Объединенная дирекция государственных природных заповедников \\ и нацииональных парков Хабаровского края, Россия \\ *e-mail: volodinsvoc@gmail.com
}

\begin{abstract}
Пассивный акустический мониторинг широко применяется для получения точной информации об использовании местообитаний и перемещений различных видов животных на охраняемых природных территориях и в туристических зонах. Данное исследование вокальной гонной активности изюбрей (Cervus elaphus xanthopygus) было проведено на территории заповедника «Большехехцирский» (Дальний Восток

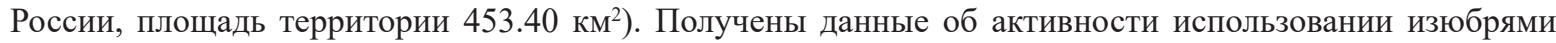
трех мест наиболее интенсивного гона. Гонные ревы были записаны в течение пяти минут в час на протяжении 58 суток периода гона в 2017 г. с помощью трех автоматических звуковых ловушек, по одной в каждом месте гона с параллельной регистрацией температуры воздуха раз в час. Всего было записано 3474 гонных рева (1538, 1159 и 777 соответственно в трех точках записи). На всех трех точках записи вокальная активность показывала сходную и четкую сезонную динамику: начальная фаза гона, активная фаза гона и фаза затухания гона. Хотя корреляция между средними за сутки значениями вокальной активности в трех точках была положительной и высоко достоверной, среднее число ревов в час различалось между точками. Это свидетельствовало о количественных различиях в использовании этих трех мест изюбрями в течение гона. Во всех трех точках записи величина средней почасовой активности рева зависела от времени суток. Во всех точках записи активность рева была наивысшей с 03:00 до 06:00 и почти прекращалась с 10:00 до 18:00. Во всех точках записи число ревов в час постепенно возрастало с 20:00 до 03:00 до максимума и затем быстро снижалось до минимальной величины с 06:00 до 09:00. Температура оказывала меньшее влияние на вокальную активность в течение суток по сравнению со временем суток. Полученные данные обсуждаются с аналогичными данными по вокальной активности другой дальневосточной популяции изюбря, обитающей в Уссурийском заповеднике.
\end{abstract}

Ключевые слова: гонный рев, заповедные территории, изюбрь, копытные, менеджмент, суточная и сезонная динамика 